\title{
Use of Non-Woven Polyethylene Terephthalate (PET) Tissue to improve Certain Properties of Concrete
}

\author{
Sifatullah Bahij ${ }^{12}$, Safiullah Omary ${ }^{1}$, Francoise Feugeas $^{1}$, Amanullah Faqiri ${ }^{2}$ \\ ${ }^{1}$ Icube, UMR CNRS 7357, INSA de Strasbourg, 24 Boulevard de la Victoire, 67084, University of Strasbourg, \\ France \\ ${ }^{2}$ Department of Civil and Industrial Construction, Kabul Polytechnic University, Kabul, Afghanistan \\ sifatullah.bahij@insa-strasbourg.fr; safiullah.omary@insa-strasbourg.fr; francoise.feugeas@insa-strasbourg.fr; \\ engafaqiri@gmail.com
}

\begin{abstract}
Nowadays plastic is closely linked to the way of our life. The annual consumption of plastics has been increasing gradually. The inadequate disposal of plastic has been resulted in major environmental problems due to the shortage of space for landfilling and low biodegradability. The reuse of plastic wastes as construction materials provides a remarkable future market for waste recycling. This work aims to study the possibility of Evolon ${ }^{\circledR}$ plastic non-woven sheets in concrete mixtures. For this purpose, an experimental study was conducted to investigate some properties of the ordinary concrete wrapped by non-woven PET plastic sheets. Samples with five various configurations; reference, 1-layer, 2-sides, 3-sides, and full wrapped were considered and prepared. The compressive, flexural, and split tensile strengths and ultrasonic pulse velocity (UPV) were measured. The outcomes of the study highlight that the compressive strength was improved for the wrapped samples, particularly for the cylindrical specimens. In addition, split tensile and flexural strengths of the wrapped samples improved significantly compared to the reference ones at each strengthened configuration. Moreover, it was observed that reference samples were damaged to many parts after mechanical testing, while wrapped specimens were taken by the applied configurations and were not separated into many small fragments. Therefore, non-woven fabrics are recommended to improve certain properties of the concrete.
\end{abstract}

Keyword: Evolon ${ }^{\circledR}$ Non-woven sheets, Mechanical behaviors, Crack pattern, Ultrasonic pulse velocity

\section{Introduction}

In recent decades, large quantities of non-degradable wastes, especially plastic wastes have caused many environmental challenges. Besides, these wastes are considered to be one of the most hazardous sources of pollution [1-6]. Recycling and reuse of plastic wastes play an important role in sustainable waste management. The aim of waste management is to save natural resources, decrease pollution of the environment, and reduce embodied energy [7].

Plastic wastes are used in many Civil Engineering applications such as; partial replacement of aggregate in concrete, strength and durability enhancement of road construction and pavement, insulating of building construction, a raw material for textile production, etc. [8]. Totally 359 million tons of plastic were manufactured worldwide in 2018, whereas 64.4 million tons of plastic were only produced in Europe in the mentioned year. In 2018, 32.5\% of such waste was recycled, $42.6 \%$ was used for energy recovery, and $24.9 \%$ was landfilled worldwide [8-11].

PET is a kind of thermoplastic that is used in many applications like blown bottles, soft drink bottles, packing, and food containers, etc. In the year 2007, PET consumption was about 10 million tons all over the world, which was equivalent to 250 billion bottles, and this figure rises about 15\% per year. Mostly PET bottles thrown away after single usage and their wastes are landfilled which causes many environmental problems. Therefore, another possible solution to overcome these environmental problems is the incorporation of PET waste as a plastic aggregate or plastic fiber into concrete mixtures $[8,12,13]$.

Experimental work was performed to investigate the structural behaviors of the lightweight concrete containing $10 \%$, $20 \%, 30 \%, 40 \%$, and $50 \%$ of waste plastic aggregates replaced by natural ones. The results indicate that the workability of concrete mixtures was remarkably decreased, while plastic aggregates were incorporated into concrete mixtures [14]. The lightweight concrete that contains PET plastic waste aggregates between 1-10\% by weight of cement was experimentally explored and the outcomes have highlighted that the compressive strength decreased with the increase of waste plastic 
content. It is due to the low adhesive strength between plastic aggregates and cement paste [15]. Moreover, a research study was conducted to investigate behaviors of the concrete with $10 \%, 20 \%$, and $30 \%$ of E-plastic waste substituted by both fine and coarse aggregates. A remarkable drop was recorded in the flexural strength with an increase in the percentage of plastic waste [16]. Similar results were documented that the tensile splitting strength enhanced for concrete mixtures with PET fibers up to $10 \%$ and then reduced back for $15 \%$ and $20 \%$ of PET fibers [17]. Furthermore, a research study was performed to explore the ultrasonic pulse velocity (UPV) of the cementitious composites containing $0 \%, 30 \%, 40 \%, 50 \%$, and $60 \%$ of PET waste aggregates. The authors found that UPV value noticeably decreased with the increase of the percentage of waste aggregates because of PET low unit weight [18].

On the other hand, the strengthening and retrofitting of structural elements is not a new subject in Civil Engineering, but plenty of research works have conducted and underlined that strengthening and retrofitting is the most suitable and economical way to enhance their structural behaviours and service life [19-21]. Besides, different types of cementitious materials [22], FRP composites, etc. have been utilized to strengthen structural members.

It has been summarized from the above literature that researchers have conducted enough work on plastic wastes that were substituted by aggregates or added into concrete mixtures as fibers. However, none of them considered such recycled plastic waste as a layer to strengthen concrete samples. Therefore, the aim of this research study is to investigate certain properties of normal concrete containing PET non-woven tissue as a layer with different configurations and their results were compared.

\section{Experimental Work}

Ordinary Portland Cement named GHORI was used confirming to ASTM C150 [23] and manufactured by Pole-Khomri Company inside Afghanistan with a specific gravity of 3.041 , Blaine surface area of $2900 \mathrm{~cm}^{2} / \mathrm{gr}$. Two types of crushed coarse aggregates and natural river sand as fine aggregates were used for the production of concrete mixtures. In addition, a new generation of polycarboxylate-based superplasticizer named ADIUM 150 certified by EN 934-2 [24] was added to improve the workability of concrete mixtures. Evolon ® non-woven tissue produced by FREUDENBERG Company was applied to strengthen all specimens as shown in Fig. 1.

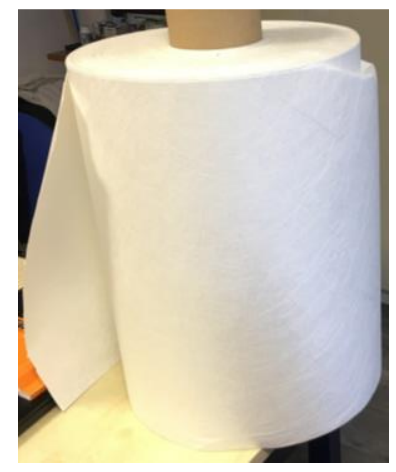

Fig. 1: Non-woven PET plastic tissue

The mix proportion of concrete is designed based on the ACI Standard Practice ACI 291.1 [25] which contains a constant w/c ratio of 0.45 and a total binder content of $455 \mathrm{~kg} / \mathrm{m}^{3}$. Before casting the specimens, molds were oiled for easy demolding, and then non-woven tissues were placed in molds according to their configurations, as presented in Table 1. Thereafter, concrete was poured into the molds and was kept inside molds for 24 hours, and finally, all the samples were cured inside the curing tank for 28 days under a normal temperature of $(20 \pm 2) \mathrm{C}^{\circ}$. 
Table 1: Samples' sizes and descriptions

\begin{tabular}{|c|c|c|c|}
\hline $\begin{array}{l}\text { Samples type } \\
\text { and sizes }\end{array}$ & Name & Description & Conducted tests \\
\hline \multirow{4}{*}{$\begin{array}{l}\text { Cube } \\
(100 \mathrm{~mm})\end{array}$} & Ref & No sheet & Compressive strength and UPV \\
\hline & 1-layer & $\begin{array}{l}\text { A layer of non-woven sheet at } \\
\text { the bottom }\end{array}$ & Compressive strength and UPV \\
\hline & 2-sides & $\begin{array}{l}\text { Non-woven sheets at two } \\
\text { vertical opposite sides }\end{array}$ & Compressive strength and UPV \\
\hline & 4-sides & $\begin{array}{c}\text { Non-woven sheets at all four } \\
\text { vertical sides }\end{array}$ & Compressive strength \\
\hline \multirow{2}{*}{$\begin{array}{l}\text { Cylinder } \\
(100 \times 200) \\
\mathrm{mm}\end{array}$} & Ref & No sheet & $\begin{array}{l}\text { Compressive and split tensile } \\
\text { strengths }\end{array}$ \\
\hline & Layer & $\begin{array}{l}\text { Completely covered with non- } \\
\text { woven sheets }\end{array}$ & $\begin{array}{l}\text { Compressive and split tensile } \\
\text { strengths }\end{array}$ \\
\hline \multirow{4}{*}{$\begin{array}{c}\text { Beam } \\
(100 \times 100 \times 500) \\
\mathrm{mm}\end{array}$} & Ref & No sheet & Flexural strength \\
\hline & 1-layer & $\begin{array}{l}\text { A layer of non-woven sheet at } \\
\text { the bottom }\end{array}$ & Flexural strength \\
\hline & 2-sides & $\begin{array}{l}\text { Non-woven sheets at two } \\
\text { vertical opposite sides }\end{array}$ & Flexural strength \\
\hline & 3 -sides & $\begin{array}{l}\text { Non-woven sheets at two } \\
\text { vertical opposite sides and } \\
\text { bottom }\end{array}$ & Flexural strength \\
\hline
\end{tabular}

\section{Results and Discussions}

\subsection{Compressive Strength}

The results of the compressive strength are shown in Table 2 and Fig. 2. The findings indicate that applying non-woven sheets to strengthen samples has a minor effect on cube compressive strength. However, the compressive strength of cylindrical specimens covered with non-woven fabrics has remarkably improved compared to the reference ones as presented in Table 2 and Fig. 2b. This is due to the ability of non-woven sheets to restrain cracks extension, alter cracking direction and delay cracking growth rate, therefore, more energy is required for the propagation of cracks inside samples and samples failure.

Table 2: Compressive strength of concrete specimens after 28 days

\begin{tabular}{ccc}
\hline $\begin{array}{c}\text { Type of } \\
\text { sample }\end{array}$ & Name & $\begin{array}{c}\text { Compressive } \\
\text { strength (MPa) }\end{array}$ \\
\hline \multirow{4}{*}{ Cube } & Ref & 29.81 \\
& 1-layer & 30.55 \\
& 2-sides & 31.21 \\
& 4-sides & 31.84 \\
\hline \multirow{2}{*}{ Cylinder } & Ref & 25.54 \\
& Layer & 28.95 \\
\hline
\end{tabular}




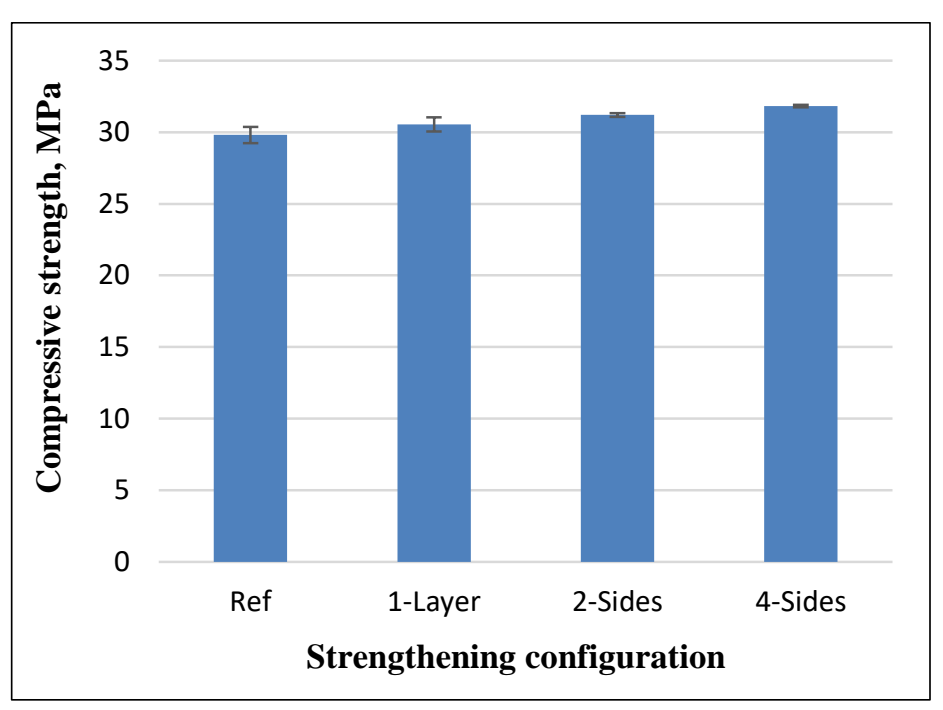

$a$

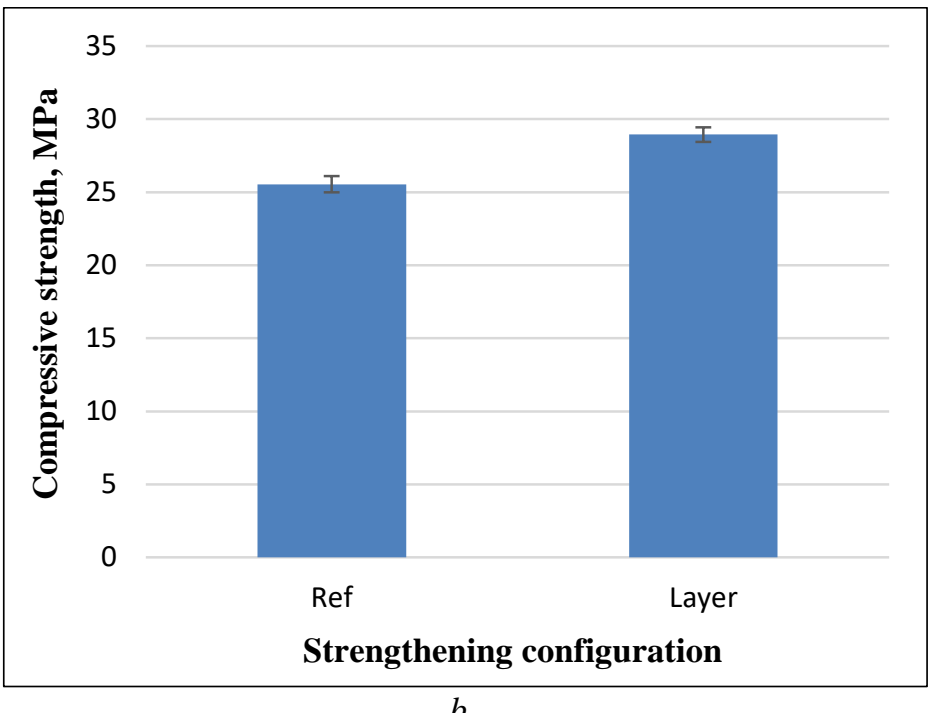

b

Fig. 2: a) cubical compressive strength, and b) cylindrical compressive strength

Moving to the crack pattern, it was observed that reference samples were damaged into many parts after the ultimate load, but samples of 1-layer, 2-sides, and 4-sides configurations were not separated into many fragments and were taken by such layers especially the faces which were strengthened by the layer, as shown in Fig. 3. For the cylindrical samples, a nonwoven plastic sheet plays a more significant role to save the samples from separation as presented in Fig. 4. This behavior of non-woven plastic sheets can be more beneficial in the case of sudden failure especially earthquake damages. It means that the building elements strengthened by such sheets will be safer than members without non-woven sheets during an earthquake.

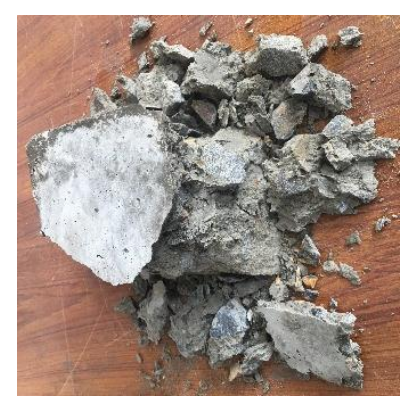

$a$

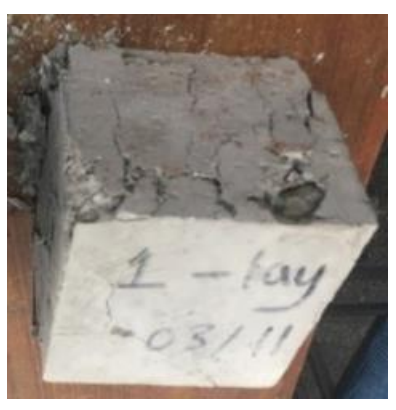

$b$

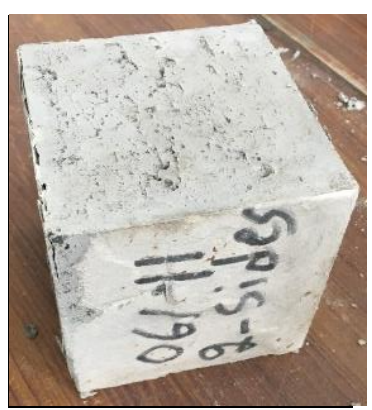

$c$

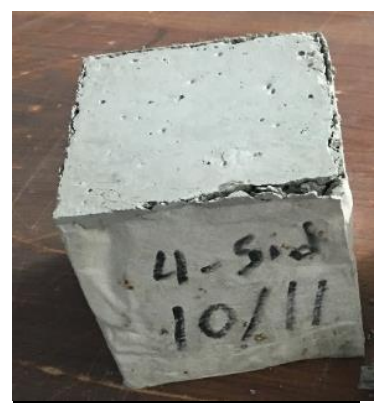

$d$

Fig. 3: Cracking pattern after the cubical compression test a) Ref, b) 1-layer, c) 2-sides, and d) 4-sides 


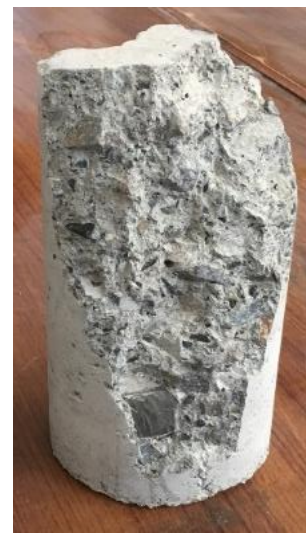

$a$

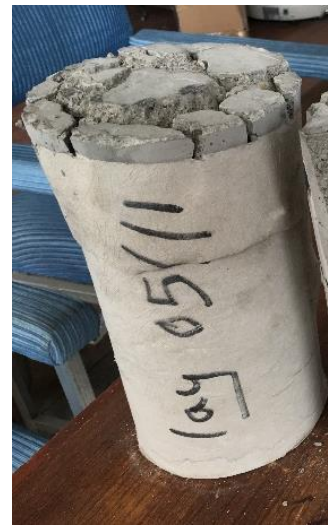

$b$

Fig. 4: Cracking pattern after the cylindrical compression test a) Ref and b) covered samples

\subsection{Flexural Strength}

The results are shown in Table 3 and Fig. 5 and reported that the flexural strength has enhanced remarkably for the beams strengthened by non-woven sheets compared to the reference ones. It was clearly observed that 3-sides strengthened beams had the highest ultimate load capacity followed by 2 -sides and 1-layer. This can be attributed to the fact that attachment of the sheets leads to delay the crack propagation and more load is required to damage the specimens because non-woven sheets play as a strengthening material.

Table 3: Flexural strength of concrete specimens after 28 days

\begin{tabular}{cc}
\hline Name & $\begin{array}{c}\text { Flexural Strength } \\
\text { (MPa) }\end{array}$ \\
\hline Ref & 3.06 \\
1-layer & 3.44 \\
2-sides & 3.68 \\
3-sides & 4.12 \\
\hline
\end{tabular}

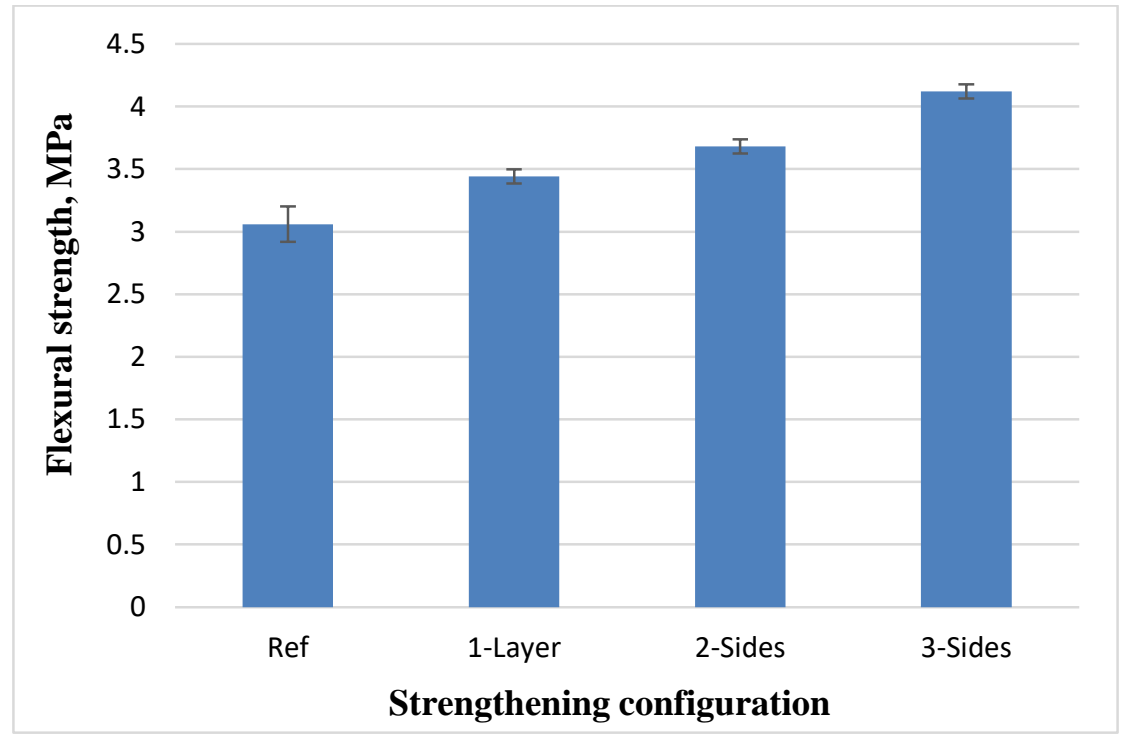

Fig. 5: Flexural strength of concrete 
On the other hand, modes of failure for all the strengthened beams were similar to the control specimens, where flexural cracks initiated at the mid-span between two loading points, propagated to the depth of the beams, and followed by a single widen crack up to the ultimate failure. As a comparison, the control beams were failed suddenly and separated into two separate parts during ultimate loading. However, beams with 1-layer, 2-sides, and 3-sides were cracked and showed somewhat ductile behaviors but not parted into two portions and were taken by the layers of non-woven sheets. In addition, widen cracks were observed for the control beams and the crack width has decreased for the beams strengthened by nonwoven plastic sheets, as shown below in Fig. 6.

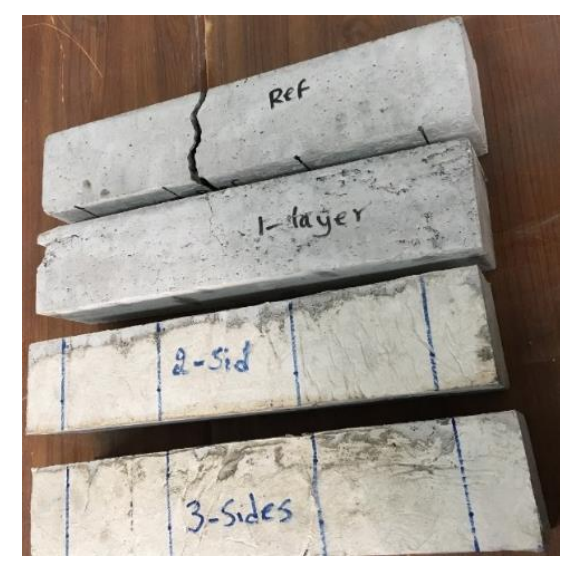

Fig. 6: Cracking pattern of the beams

\subsection{Split Tensile Strength}

The outputs of the splitting tensile strength are shown in Table 4 and Fig. 7. The results clearly illustrate that the split tensile strength has significantly enhanced for the cylinders covered with non-woven sheets compared to the non-covered ones. This is due to non-woven fabrics bridging cracks, preventing early damage, and necessitating more energy to fail the samples.

Table 4: Split tensile strength of concrete specimens after 28 days

\begin{tabular}{cc}
\hline Name & Split tensile \\
strength (MPa) \\
Ref & 2.63 \\
Layer & 3.03 \\
\hline
\end{tabular}




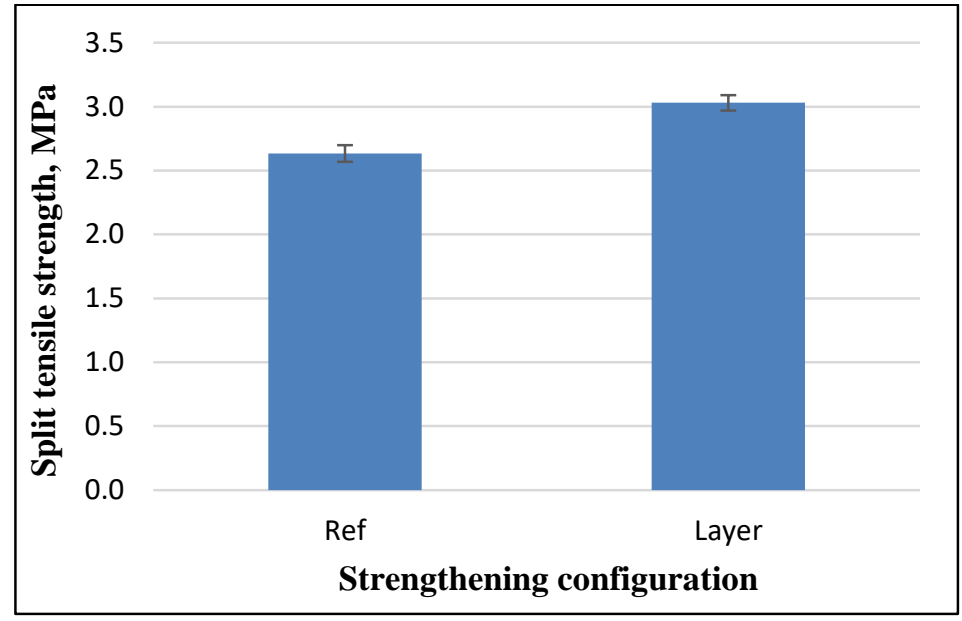

Fig. 7: Split tensile strength of concrete

The failure mode of the reference cylinders after the tensile splitting test was brittle fracture and specimens were completely divided into two separate parts. Whereas, specimens covered with non-woven fabrics were not separated and were taken by the sheets. This means that the attachment of plastic sheets makes the samples to sustain more splitting loads and the final fracture will be without brittle behaviors as shown in Fig. 8. These findings prove the prevention of catastrophic failure, while structural elements are subjected to such loads.

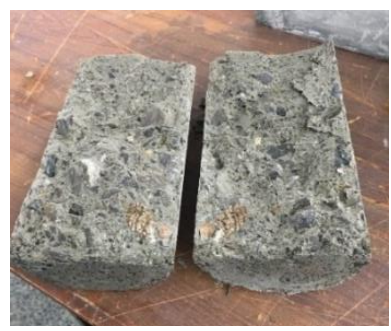

$a$

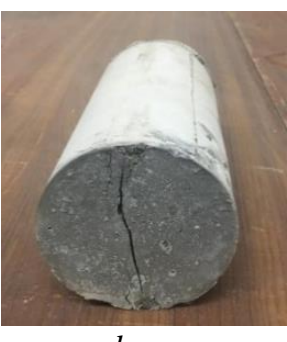

$b$

Fig. 8: Cracking pattern after split tensile test $a$ ) Ref, and $b$ ) covered samples

\subsection{Ultrasonic Pulse Velocity (UPV) Test}

UPV value means to assist the transit time of ultrasonic pulses from concrete and depends on the density and elastic properties of concrete. The findings of the UPV test are presented in Table 5 and Fig. 9. It can be clearly observed that the attachment of non-woven sheets on concrete samples led to a remarkable decrease in UPV values compared to the reference samples. This can be attributed to the fact that the pulse velocity is less in plastic compared to the concrete.

Table 5: UPV values for the concrete specimens after 28 days

\begin{tabular}{cc}
\hline Name & UPV $(\mathbf{m} / \mathbf{s})$ \\
\hline Ref & 4646 \\
1-Layer & 4077 \\
2-Sides & 3627 \\
\hline
\end{tabular}




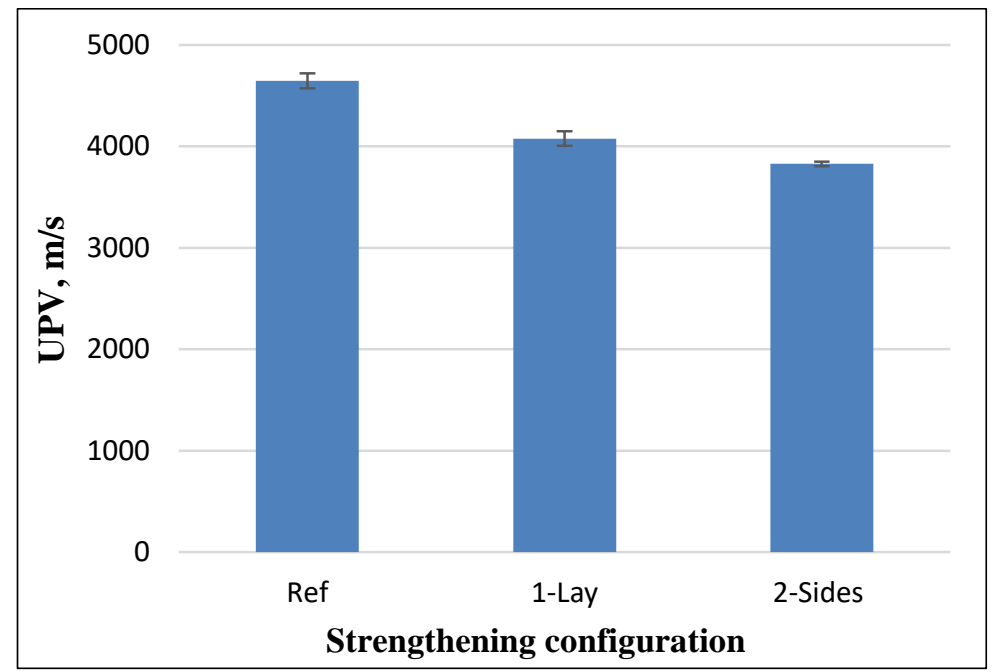

Fig. 9: Ultrasonic pulse velocity of concrete

\section{Conclusions}

Based on the outcomes illustrated above, the main concluding points can be described as follows:

- The attachment of non-woven tissue has a minor effect on cube compressive strength, whereas such strength improved significantly for cylindrical samples covered by non-woven fabrics. Moreover, at the ultimate compressive load, samples with non-woven tissue were not separated into many parts like reference ones.

- Flexural strength of the beams strengthened by 1-layer, 2-sides, and 3-sides of non-woven sheets is higher than the control ones. In addition, the control beams had a brittle failure and were separated into two parts but beams having 1-layer, 2-sides, and 3-sides of non-woven tissue showed somewhat ductile behavior and were not divided into two portions, and had less widen cracks than the control beams.

- The splitting tensile strength has significantly enhanced for the cylinders covered with non-woven sheets compared to the non-covered cylinders. Similar to other mechanical properties, non-covered cylinders were absolutely divided into two separate parts, while covered samples were taken by non-woven tissue after peak load.

- The highest UPV value was achieved for the control specimens, while the lowest UPV value was recorded from the samples having non-woven sheets at two opposite sides.

- Since no research is performed to consider non-woven plastic sheets in cementitious materials. Thus, this study only confirms that such fabrics are possible to be used in concrete due to good bonds with specimens and have the ability to improve certain properties of concrete as well. Therefore, more investigations are required to study other properties rather than mechanical ones such as physical, thermal, durability, microstructural analysis, resistance in severe environments, etc. However, the fact behind the bond between non-woven sheets and cementitious materials needs further investigation.

\section{Acknowledgements}

Thanks to the technical staff at the laboratory of Kabul Polytechnic University of Afghanistan for their help and support.

\section{References}

[1] Ismail ZZ, Al-hashmi EA. Use of waste plastic in concrete mixture as aggregate replacement. Waste Management 2007;28:2041-2047. https://doi.org/10.1016/j.wasman.2007.08.023.

[2] Al-Salem SM, Lettieri P, Baeyens J. Recycling and recovery routes of plastic solid waste (PSW): A review. Waste Management 2009;29:2625-43. https://doi.org/10.1016/j.wasman.2009.06.004. 
[3] Liguori B, Iucolano F, Capasso I, Lavorgna M, Verdolotti L. The effect of recycled plastic aggregate on chemicophysical and functional properties of composite mortars. Materials and Design 2014;57:578-84. https://doi.org/10.1016/j.matdes.2014.01.006.

[4] Iucolano F, Liguori B, Caputo D, Colangelo F, Cioffi R. Recycled plastic aggregate in mortars composition: Effect on physical and mechanical properties. Materials and Design 2013;52:916-22. https://doi.org/10.1016/j.matdes.2013.06.025.

[5] Guerrero LA, Maas G, Hogland W. Solid waste management challenges for cities in developing countries. Waste Management 2013;33:220-32. https://doi.org/10.1016/j.wasman.2012.09.008.

[6] Wu G, Li J, Xu Z. Triboelectrostatic separation for granular plastic waste recycling: A review. Waste Management 2013;33:585-97. https://doi.org/10.1016/j.wasman.2012.10.014.

[7] Ghernouti Y, Rabehi B, Bouziani T, Ghezraoui H, Makhloufi A. Fresh and hardened properties of seglf-compacting concrete containing plastic bag waste fibers (WFSCC). Construction and Building Materials 2015;82:89-100. https://doi.org/10.1016/j.conbuildmat.2015.02.059.

[8] Kamaruddin MA, Abdullah MMA, Zawawi MH, Zainol MRRA. Potential use of Plastic Waste as Construction Materials : Recent Progress and Future Prospect. IOP Conf Series: Materials Science and Engineering 2017;267. https://doi.org/10.1088/1757-899X/267/1/012011.

[9] Franco-García M-L, Carpio-Aguilar JC, Bressers H. Towards Zero Waste, Circular Economy Boost: Waste to Resources. Greening of Industry Networks Studies 2019;6:1-8. https://doi.org/https://doi.org/10.1007/978-3-31992931-6_1.

[10] Mrowiec B. Plastics in the circular economy (CE). The Journal of Institute of Environmental Protection-National Research Institute 2018;29:16-9. https://doi.org/DOI 10.2478/oszn-2018-0017.

[11] Plastic E. Plastics - the Facts 2019 An analysis of European plastics production, demand and waste data. Available Online:

Https://WwwPlasticseuropeOrg/Application/Files/9715/7129/9584/FINAL_web_version_Plastics_the_facts2019_141 02019Pdf 2019.

[12] Frigione M. Recycling of PET bottles as fine aggregate in concrete. Waste Management 2010;30:1101-6. https://doi.org/10.1016/j.wasman.2010.01.030.

[13] Bahij S, Omary S, Feugeas F, Faqiri A. Fresh and hardened properties of concrete containing different forms of plastic waste - A review. Waste Management 2020;113:157-75. https://doi.org/10.1016/j.wasman.2020.05.048.

[14] Pavlík Z, Záleská M, Pavlíková M, Pokorny J, Robert C. Structural , mechanical and hygrothermal properties of lightweight concrete based on the application of waste plastics. Construction and Building Materials 2018;180:1-11. https://doi.org/10.1016/j.conbuildmat.2018.05.250.

[15] Hameed M, Ahmed BA. Employment the plastic waste to produce the light weight concrete. Energy Procedia 2019;157:30-8. https://doi.org/10.1016/j.egypro.2018.11.160.

[16] Ashwini MBT. Partial replacement of E-plastic Waste as Coarse-aggregate in Concrete. Procedia Environmental Sciences 2016;35:731-9. https://doi.org/10.1016/j.proenv.2016.07.079.

[17] Vali M, Asadi SS. PET bottle waste as a supplement to concrete fine aggregate. International Journal of Civil Engineering and Technology 2017;8:558-68.

[18] Akçaözog K, Atis CD. Thermal conductivity , compressive strength and ultrasonic wave velocity of cementitious composite containing waste PET lightweight aggregate (WPLA). Composites: Part B 2013;45:721-6. https://doi.org/https://doi.org/10.1016/j.compositesb.2012.09.012.

[19] Jawdhari A, Peiris A, Harik I. Experimental study on RC beams strengthened with CFRP rod panels. Engineering Structures 2018;173:693-705. https://doi.org/10.1016/j.engstruct.2018.06.105.

[20] Hosen A, Zamin M, Alengaram UJ, Sulong NHR. CFRP strips for enhancing flexural performance of RC beams by SNSM strengthening technique. Construction and Building Materials 2018;165:28-44. https://doi.org/10.1016/j.conbuildmat.2017.12.052.

[21] Adel A, Hamed A, El-kashif KFO. Flexural strengthening of preloaded reinforced concrete continuous beams : An 
experimental investigation. Alexandria Engineering Journal 2018. https://doi.org/10.1016/j.aej.2018.11.011.

[22] Bahij S, Omary S, Feugeas F, Faqiri A. Structural Strengthening/Repair of Reinforced Concrete (RC) Beams by Different Fiber-Reinforced Cementitious Materials - A State-of-the-Art Review. Journal of Civil and Environmental Engineering 2020;10. https://doi.org/10.37421/jcde.2020.10.354.

[23] ASTM C150. Standard Specification for Portland Cement. American Society for Testing and Materials 2009.

[24] EN 934-2. Admixtures for concrete, mortar and grout. European Standard 2012.

[25] ACI 211.1-91. Standard Practice of Selecting Proportions for Normal, Heavyweight, and Mass Concrete. ACI Manual of Concrete Practice, Part 1: Materials and General Properties of Concrete, Detroit, Michigan 1994. 